\title{
Effects of Long-term Irrigation with Water from Wastewater Receiving River on Soil Chemical and Microbiological Properties in Hebei, China
}

\author{
Rutai Gao ${ }^{1}$, Qiong Liang ${ }^{1}$, Yuan Zhang ${ }^{1,2}$, Hui Zhang ${ }^{1}$, Wenbin Tan ${ }^{1}$, Lina Ma ${ }^{1,3}$, Beidou Xi ${ }^{1 *}$ \\ ${ }^{1}$ State Key Laboratory of Environmental Criteria and Risk Assessment, Chinese Research Academy of Environmental \\ Sciences, Beijing 100012, China \\ ${ }^{2}$ Department of Resource and Environment Science, Wuhan University, Wuhan 430079, China \\ ${ }^{3}$ Agricultural College of Guangxi University, Nanning 530004, China
}

\begin{abstract}
In arid and semi-arid regions in China, a large amount of treated wastewater is discharged into rivers that supply water for agriculture. Treated wastewater contains not only valuable nutrients, but also toxic contaminants that might affect soil quality. This study investigated how long-term irrigation with water from a wastewater receiving river affected soil chemical and microbiological properties in Hebei Province, China. Soil samples were collected from three river water irrigated fields adjacent to Wangyang River, and three groundwater irrigated fields far from the river. The results showed that irrigation with river water for more than 20 years had significantly increased dissolved organic $C$, microbial biomass $C$ and permanganate oxidizable $C$ contents, and $\beta$-glucosidase, urease, alkaline phosphatase, arylsulphatase and dehydrogenase activities in the surface soil, reflecting a stimulated microbial activity in river water irrigated soils. Long-term irrigation with river water has also resulted in accumulation of $\mathrm{Hg}, \mathrm{Cd}, \mathrm{As}, \mathrm{Pb}, \mathrm{Cu}, \mathrm{Cr}$ and $\mathrm{Zn}$ in the soil, and may pose potential risk to soil quality and food safety. We conclude that although the river water irrigation has beneficial effects on soil microbiological characteristics, a controlled irrigation management based on periodic monitoring of soil quality parameters is needed to ensure its safe and long-term use in agriculture.
\end{abstract}

Keywords- treated wastewater; irrigation; heavy metal; labile soil organic carbon; enzyme activities

\section{INTRODUCTION}

Reuse of wastewater in agriculture has been increasingly practiced all over the world because of the water resource scarcity, especially in arid and semi-arid regions. In China, wastewater has been used in irrigation of crops for over 50 years, and more than 3.3 million ha of the arable land is currently irrigated with domestic or industrial wastewater[1]. Irrigation with wastewater may result in accumulation of heavy metals and toxic organic contaminants in the soil, and increase soil salinity if the electrical conductivity (EC) is high, and thus have negative impacts on soil quality and crop production. Therefore, wastewater is recommended for use in agriculture after treated and under controlled conditions to minimize hazards from toxic contaminants. The effects of irrigation with treated wastewater on soil quality has been intensively studied in recent years[2,3], but mainly focused on the direct use of wastewater for irrigating crops. In fact, most of the treated wastewater from wastewater treatment plant is discharged into rivers that supply water for agriculture. Thus, irrigation with these river water may also have impact on soil parameters, such as $\mathrm{pH}$, salinity, nutrient conditions and contents of toxic contaminants[4]. Research on the changes of soil quality after long-term irrigation with water from the wastewater receiving river is therefore necessary.

Hebei is a typical province in north China that has a water shortage problem. The annual reuse of wastewater was approximately 251 million $\mathrm{m}^{3}$ in this area[1]. The Wangyang River is located near the city of Shijiazhuang, the capital of Hebei province. Effluents from chemical, pharmaceutical and textile factories, the major industries that produce up to more than $30 \mathrm{Mm}^{3}$ wastewaters year ${ }^{-1}$ in the High-Tec Industrial Development Zone of Shijiazhuang, are discharged into the Wangyang River after secondary biological treatments. Farmlands adjacent to the Wangyang River have been irrigated using river water for almost 20 years. Although treated before discharging into the river, the effluents also contained considerable contents of nutrients and toxic contaminants, and may result in pollution of the river water. Previous studies had showed that the $\mathrm{COD}$ and $\mathrm{NH}_{3}-\mathrm{N}$ concentrations in the river water have exceeded the allowed limit severely[5], and $\mathrm{Cr}, \mathrm{Cu}, \mathrm{Cd}$, $\mathrm{Pb}$ and $\mathrm{Zn}$ were found accumulated in surface sediments of the Wangyang River[6]. However, little is known about how the long-term irrigation with this river water has affected the soil quality. The objective of our study was to evaluate changes in soil chemical and microbiological properties after long-term irrigation with water from the Wangyang River. The results will help to select a proper irrigation management practice for maintaining and improving soil health and quality in this area.

\section{MATERIALS AND METHODS}

\section{A. Study area and soil sampling}

The study area was located near the city of Shijiazhuang $\left(114^{\circ} 29^{\prime} \mathrm{E}, 38^{\circ} 03^{\prime} \mathrm{N}\right)$ in Hebei Province, China. This area lies in the North China Plain and is characterized by a semi-arid climate. The mean annual temperature is $13.1^{\circ} \mathrm{C}$ and mean annual precipitation is $556 \mathrm{~mm}$, mainly in the period from July to September. A summer maize (Zea mays 
L.) - winter wheat (Triticum aestivum L.) rotation is the predominant cropping system in this area, covering up to $60 \%$ of the arable land. The farmland had similar management practices and received organic and mineral fertilizers simultaneously.
In this area, the fields were irrigated with different water: groundwater $(\mathrm{GW})$, and river water $(\mathrm{RW})$ from the Wangyang River. The values of EC, COD, $\mathrm{NH}_{3}-\mathrm{N}, \mathrm{TN}$ and $\mathrm{TP}$ in the river water were all much higher than those in groundwater (Table 1).

TABLE I. SELECTEd PHYSICAL AND CHEMICAL CHARACTERISTICS OF IRRIGATION WATER.

\begin{tabular}{|c|c|c|c|c|c|c|c|c|}
\hline & $\mathrm{pH}$ & $\begin{array}{c}\mathrm{EC} \\
\left(\mu \mathrm{S} \mathrm{cm}^{-1}\right)\end{array}$ & $\begin{array}{c}\mathrm{DO} \\
\left(\mathrm{mg} \mathrm{L}^{-1}\right)\end{array}$ & $\begin{array}{c}\mathrm{BOD}_{5} \\
\left(\mathrm{mg} \mathrm{L}^{-1}\right)\end{array}$ & $\begin{array}{c}\mathrm{COD} \\
\left(\mathrm{mg} \mathrm{L}^{-1}\right)\end{array}$ & $\begin{array}{c}\mathrm{TN} \\
\left(\mathrm{mg} \mathrm{L}^{-1}\right)\end{array}$ & $\begin{array}{c}\mathrm{TP} \\
\left(\mathrm{mg} \mathrm{L}^{-1}\right)\end{array}$ & $\begin{array}{c}\mathrm{NH}_{3}-\mathrm{N} \\
\left(\mathrm{mg} \mathrm{L}^{-1}\right)\end{array}$ \\
\hline \multirow{2}{*}{$\begin{array}{l}\text { GW } \\
\text { RW }\end{array}$} & $7.26(0.04)$ & $1421(56)$ & $3.70(0.19)$ & - & $34.84(1.38)$ & $3.24(1.59)$ & $0.05(0.02)$ & $0.29(0.04)$ \\
\hline & $7.90(0.07)$ & $4920(683)$ & $0.96(0.27)$ & $23.00(6.46)$ & $214.1(28.0)$ & $33.98(0.45)$ & $1.72(0.83)$ & $12.13(3.17)$ \\
\hline
\end{tabular}

Means of three triplicates with standard deviation in parenthesis.

The soil samples were collected at six different sites. Site 1, 2 and 3 were located at about $10 \mathrm{~km}$ east of the Wangyang River, where irrigation of the fields only occurred with groundwater (as control). Site 4, 5 and 6 were located adjacent to the Wangyang River and irrigated with river water for more than 20 years. All of the selected sites had been farmed conventionally, according to the local practice. At each sampling site, three replicates were taken and altogether 18 soil spots were collected.

Soil sampling was performed in September 2012 and May 2013. The crops at sampling time were summer maize and winter wheat, respectively. All soil samples were taken from the plough layer $(0-20 \mathrm{~cm})$ with a soil core sampler $(10 \mathrm{~cm}$ diameter). Field-moist soil from each spot was divided into two parts after removing stones, visible roots and fauna. One part was air-dried at room temperature and ground up to pass through a $2 \mathrm{~mm}$ sieve for physical and chemical analyses. The other part was sieved ( $2 \mathrm{~mm}$ mesh) and frozen for biochemical analyses.

\section{B. Soil assays}

Soil $\mathrm{pH}$ was measured with a PHS-3C $\mathrm{pH}$ meter and soil electrical conductivity (EC) was measured using a model DDS-307 conductivity meter. Soil texture was determined using pipette method[7]. Soil samples for soil organic C (SOC) measurements were pretreated with $0.5 \mathrm{M} \mathrm{HCl}$ to remove carbonates and then ball-milled. SOC concentration was determined by dry combustion. Total concentrations of heavy metals were analyzed by the methods described by $\mathrm{Bao}[8]$. Concentrations of $\mathrm{Cd}, \mathrm{Pb}, \mathrm{Cu}, \mathrm{Cr}$ and $\mathrm{Zn}$ were determined using flame atomic absorption spectrometry, and those of $\mathrm{Hg}$ and As were determined by an atomic fluorescence spectrometry.

Soil microbial biomass $\mathrm{C}(\mathrm{MBC})$ was determined using chloroform fumigation-extraction method on fresh soils[9]. Soil MBC was calculated by dividing the differences of extractable $\mathrm{C}$ between fumigated and unfumigated soils with a conversion factor of 0.45 . The extractable $\mathrm{C}$ of unfumigated soils can be considered as the background dissolved organic $\mathrm{C}$ (DOC)[10]. The permanganate oxidizable $\mathrm{C}\left(\mathrm{KMnO}_{4}-\mathrm{C}\right)$ was estimated using the method reported by Vieira[11]. Catalase activity (CAT) was assayed using titration method as described by Zhou[12], while dehydrogenase (DEH), alkaline phosphatase (ALP), $\beta$-glucosidase (GLU), arylsulphatase (ARY) and urease (URE) activities were determined as reported by Tabatabai[13]

\section{Calculations and statistical analyses}

A student's independent samples t-test was used to identify differences of soil $\mathrm{pH}, \mathrm{EC}$, total concentrations of heavy metals, labile SOC contents and enzyme activities between the irrigation treatments. The differences were considered significant at $P<0.05$. Pearson's linear correlation was performed to evaluate the relationships between the parameters. All statistical analyses were performed with SPSS 17.0 for windows.

The sensitive index (SI) related to irrigation treatments for labile organic $\mathrm{C}$ fractions and enzyme activity was calculated using the following equation:

$\mathrm{SI}=\frac{\text { mean of RW irrigated value }- \text { mean of GW irrigated value }}{\text { mean of GW irrigated value }} \times 100$

\section{RESULTS AND DISCUSSION}

\section{A. Effect of irrigation on physical-chemical characteristics of soils}

Soils were slightly alkaline in the study area, with $\mathrm{pH}$ values ranging from 7.65 to 7.71 (Table 2). No significant difference was tested in soil $\mathrm{pH}$ between GW and RW treatments. Irrigation with the water from Wangyang River for almost 20 years had significantly increased soil EC from $130 \mu \mathrm{S} \mathrm{cm}^{-1}$ ( $\mathrm{GW}$ irrigation) to $216 \mu \mathrm{S} \mathrm{cm}^{-1}$ (RW irrigation) $(P<0.05)$. Such increase can be attributed to the input of exchangeable cations through irrigation. The increase of soil EC could influence soil physical characteristics such as aggregate stability and infiltration properties[14], result in soil salinity problem and have a negative impact on crop productivity.

Soil organic $\mathrm{C}$ content was also significantly increased after long-term RW irrigation $(P<0.05)$ (Table 2$)$. The mean SOC content was $9.31 \mathrm{~g} \mathrm{~kg}^{-1}$ in RW irrigated soils, and $7.40 \mathrm{~g} \mathrm{~kg}^{-1}$ in $\mathrm{GW}$ irrigated soils. Long-term irrigation with water rich in organic matter has generally been shown to increase SOC content in the surface soil[15]. In the present study, the increased SOC in RW irrigated soil might be partly related to the direct input of organic carbon by the 
river water, which contained a large amount of organic compounds (Table 1). Moreover, the valuable nutrients in the river water could develop crop production, promote root growth and increase amount of plant residues [16], thereby increasing the SOC pools. However, such increase of SOC under treated wastewater irrigation was not observed in some other researches[3]. This was mainly because of the low concentration of organic matter in the treated wastewater and short period of experimental time in their studies. According to Friedel, the organic $\mathrm{C}$ accumulated in soil can increase with increasing organic load in the irrigation water, and with increasing irrigation time[15].

TABLE II. Characteristics OF THE STUDIED SOIL

\begin{tabular}{|c|c|c|c|c|c|c|c|c|c|c|c|}
\hline & \multicolumn{2}{|l|}{$\begin{array}{l}\mathrm{pH} \\
\left(\mathrm{CaCl}_{2}\right)\end{array}$} & \multicolumn{2}{|l|}{$\begin{array}{l}\mathrm{EC} \\
\left(\mu \mathrm{S} \mathrm{cm}^{-1}\right)\end{array}$} & \multicolumn{2}{|l|}{$\begin{array}{l}\text { SOC } \\
\left(\mathrm{g} \mathrm{kg}^{-1}\right)\end{array}$} & \multirow[t]{2}{*}{ Sites } & \multicolumn{3}{|c|}{$\begin{array}{l}\text { Particle size distribution } \\
(\%)\end{array}$} & \multirow[t]{2}{*}{$\begin{array}{l}\text { Textural } \\
\text { classification }\end{array}$} \\
\hline & Sep 2012 & May 2013 & Sep 2012 & May 2013 & Sep 2012 & May 2013 & & Sand & Silt & Clay & \\
\hline \multirow[t]{3}{*}{$\overline{\mathrm{GW}}$} & \multirow{3}{*}{$\begin{array}{l}7.65 \\
(0.06) \\
\mathrm{A} \mathrm{a}\end{array}$} & \multirow{3}{*}{$\begin{array}{l}7.66 \\
(0.08) \\
\mathrm{A} \mathrm{a}\end{array}$} & \multirow{3}{*}{$\begin{array}{l}133 \\
(28) \\
\mathrm{A} \mathrm{b}\end{array}$} & \multirow{3}{*}{$\begin{array}{l}130 \\
(20) \\
\mathrm{A} \mathrm{b}\end{array}$} & \multirow{3}{*}{$\begin{array}{l}7.19 \\
(0.61) \\
\text { A b }\end{array}$} & \multirow{3}{*}{$\begin{array}{l}7.60 \\
(1.25) \\
\mathrm{Ab}\end{array}$} & 1 & 10.30 & 65.23 & 24.47 & Silt loam \\
\hline & & & & & & & 2 & 14.71 & 64.98 & 20.31 & Silt loam \\
\hline & & & & & & & 3 & 10.15 & 61.26 & 28.59 & Silty clay loam \\
\hline \multirow[t]{3}{*}{ RW } & \multirow{3}{*}{$\begin{array}{l}7.71 \\
(0.07) \\
\mathrm{A} \mathrm{a}\end{array}$} & \multirow{3}{*}{$\begin{array}{l}7.69 \\
(0.05) \\
\mathrm{A} \mathrm{a}\end{array}$} & \multirow{3}{*}{$\begin{array}{l}215 \\
(57) \\
\text { A a }\end{array}$} & \multirow{3}{*}{$\begin{array}{l}216 \\
(95) \\
\mathrm{A} \mathrm{a}\end{array}$} & \multirow{3}{*}{$\begin{array}{l}8.72 \\
(1.32) \\
\mathrm{A} \mathrm{a}\end{array}$} & \multirow{3}{*}{$\begin{array}{l}9.89 \\
(1.24) \\
\mathrm{A} \mathrm{a}\end{array}$} & 4 & 22.50 & 57.10 & 20.40 & Silt loam \\
\hline & & & & & & & 5 & 20.09 & 60.95 & 18.96 & Silt loam \\
\hline & & & & & & & 6 & 11.67 & 66.59 & 21.74 & Silt loam \\
\hline
\end{tabular}

Means of three triplicates with standard deviation in parenthesis. Values followed by different small letters (different treatment) and different capital letters (different sampling data) are significantly different at $P<0.05$.

Total concentrations of $\mathrm{Hg}, \mathrm{Cd}, \mathrm{As}, \mathrm{Pb}, \mathrm{Cu}, \mathrm{Cr}$ and $\mathrm{Zn}$ were all significantly higher in RW irrigated soils compared to those in GW irrigated soils $(P<0.05)$ (Table 3$)$. The largest difference was observed in $\mathrm{Hg}$ concentration, which showed a 2.6-fold increase in the soil of RW irrigated area than that of the control (GW). However, all these heavy metals did not exceed the limited concentration according to the Environmental Quality Standard for soils of China (GB 15618-1995). Therefore, the heavy metal concentrations are not a restriction in the use of river water for irrigation. Even so, the concentrations of these metals (except As) were higher than the background values in Hebei Province (Table 3), suggesting a potential risk to soil quality and food safety in the future.

Table III. Total Concentrations (Mg KG-1) Of Heavy Metals In SoILS

\begin{tabular}{llllllll}
\hline & $\mathrm{Hg}$ & $\mathrm{Cd}$ & $\mathrm{As}$ & $\mathrm{Pb}$ & $\mathrm{Cu}$ & $\mathrm{Cr}$ & $\mathrm{Zn}$ \\
\hline $\mathrm{GW}$ & $0.027(0.006) \mathrm{b}$ & $0.13(0.03) \mathrm{b}$ & $9.4(0.8) \mathrm{b}$ & $21.6(1.2) \mathrm{b}$ & $20.6(3.0) \mathrm{b}$ & $82.4(9.2) \mathrm{b}$ & $66.5(11.8) \mathrm{b}$ \\
$\mathrm{RW}$ & $0.071(0.026) \mathrm{a}$ & $0.20(0.02) \mathrm{a}$ & $10.2(0.3) \mathrm{a}$ & $25.7(2.0) \mathrm{a}$ & $29.9(10.1) \mathrm{a}$ & $91.6(3.6) \mathrm{a}$ & $81.2(4.1) \mathrm{a}$ \\
EQSC $^{\mathrm{a}}$ & 1 & 1 & 25 & 350 & 100 & 250 & 300 \\
Background value $^{\mathrm{b}}$ & 0.036 & 0.094 & 13.6 & 21.5 & 21.8 & 68.3 & 78.4 \\
\hline
\end{tabular}

Means of three triplicates with standard deviation in parenthesis. Values followed by different letters in the same column are significantly different at $P<0.05$. a: Environmental quality standard for soils of China (GB 15618-1995). b: Background value in the soils of Hebei Povince.

\section{B. Effect of irrigation on labile organic carbon fractions of soils}

Labile organic $\mathrm{C}$ fractions: $\mathrm{DOC}, \mathrm{MBC}$ and $\mathrm{KMnO}_{4}-\mathrm{C}$ were all significantly higher in the RW irrigated soils than GW irrigated soils in the surface layer (Table 4). The average contents of DOC, $\mathrm{MBC}$ and $\mathrm{KMnO}_{4}-\mathrm{C}$ were $20 \%$, $63 \%$ and $49 \%$ higher in RW irrigated soils than those in GW irrigated soils, respectively. The labile soil organic C fractions can be affected by irrigation management, and revealed the build-up of labile $\mathrm{C}$ pools under RW irrigation after more than 20 years. The significant increase in these labile organic $\mathrm{C}$ fractions suggested that they are sensitive to changes in SOC caused by irrigation management. However, the extent of changes of labile organic $\mathrm{C}$ fractions was different between the two irrigation managements. Compared to SOC (21.3-30.0\%), MBC (51.4-74.5\%) and $\mathrm{KMnO}_{4}-\mathrm{C}(47.5-51.6 \%)$ were more sensitive to irrigation practice, while DOC was increased by only $8.3-26.5 \%$ under RW treatment (Table 4). The lower sensitivity of DOC might be owing to its smaller size and highly labile nature[17].

According to Powlson, the proportion of labile organic $\mathrm{C}$ in SOC could reflect the $\mathrm{C}$ availability in the soil[18]. In this study, the $\mathrm{KMnO}_{4}-\mathrm{C} / \mathrm{SOC}$ value was significantly higher under RW treatment than under GW treatment, suggesting that long-term irrigation with river water may increase $\mathrm{C}$ availability in the soil. There were large differences in the proportions between the three labile SOC fractions. The mean value of DOC was $1.19-1.43 \%, \mathrm{MBC}$ was $2.53-3.43 \%$, and $\mathrm{KMnO}_{4}-\mathrm{C}$ was $25.37-33.12 \%$ of SOC in our study (Table 4). The difference of proportions was mainly related to the different components of each labile $\mathrm{C}$ fraction due to different extraction method. 
TABLE IV. LABILE ORGANIC C FRACTIONS AND THEIR PROPORTIONS IN SOIL ORGANIC C IN SOILS

\begin{tabular}{|c|c|c|c|c|c|c|c|}
\hline & & $\begin{array}{c}\text { DOC } \\
\left(\mathrm{g} \mathrm{kg}^{-1}\right)\end{array}$ & $\begin{array}{c}\mathrm{MBC} \\
\left(\mathrm{g} \mathrm{kg}^{-1}\right)\end{array}$ & $\begin{array}{c}\mathrm{KMnO}_{4}-\mathrm{C} \\
\left(\mathrm{g} \mathrm{kg}^{-1}\right)\end{array}$ & $\begin{array}{c}\text { DOC/SOC } \\
(\%)\end{array}$ & $\begin{array}{c}\mathrm{MBC} / \mathrm{SOC} \\
(\%)\end{array}$ & $\begin{array}{c}\mathrm{KMnO}_{4}-\mathrm{C} / \mathrm{SOC} \\
(\%)\end{array}$ \\
\hline \multirow[t]{3}{*}{ Sep 2012} & GW & $0.10(0.01) \mathrm{A} \mathrm{b}$ & $0.18(0.05) \mathrm{Ab}$ & $1.80(0.51) \mathrm{A} \mathrm{b}$ & $1.33(0.15) \mathrm{A} \mathrm{a}$ & $2.53(0.77) \mathrm{A} \mathrm{a}$ & $25.37(8.05) \mathrm{A} \mathrm{a}$ \\
\hline & RW & $0.12(0.03) \mathrm{A} \mathrm{a}$ & $0.27(0.07) \mathrm{A} \mathrm{a}$ & $2.66(0.45) \mathrm{B} \mathrm{a}$ & $1.42(0.48) \mathrm{A} \mathrm{a}$ & $3.16(0.92) \mathrm{A} \mathrm{a}$ & $30.65(4.42) \mathrm{A} \mathrm{a}$ \\
\hline & SI & 26.5 & 51.4 & 47.5 & - & - & - \\
\hline \multirow[t]{3}{*}{ May 2013} & GW & $0.11(0.02) \mathrm{A} \mathrm{a}$ & $0.20(0.07) \mathrm{A} \mathrm{b}$ & $2.15(0.39) \mathrm{A} \mathrm{b}$ & $1.43(0.25) \mathrm{A} \mathrm{a}$ & $2.59(0.82) \mathrm{A} \mathrm{a}$ & $28.52(4.64) \mathrm{A} \mathrm{a}$ \\
\hline & RW & $0.12(0.03) \mathrm{A} \mathrm{a}$ & $0.34(0.14) \mathrm{A} \mathrm{a}$ & $3.26(0.50) \mathrm{A} \mathrm{a}$ & $1.19(0.30) \mathrm{A} \mathrm{a}$ & $3.43(1.23) \mathrm{A} \mathrm{a}$ & $33.12(4.53) \mathrm{A} \mathrm{a}$ \\
\hline & SI & 8.3 & 74.5 & 51.6 & - & - & - \\
\hline \multirow[t]{3}{*}{ Mean } & GW & $0.10(0.01) \mathrm{a}$ & $0.19(0.05) \mathrm{b}$ & $1.98(0.41) b$ & $1.38(0.11) \mathrm{a}$ & $2.56(0.57) \mathrm{a}$ & $26.95(5.49) \mathrm{b}$ \\
\hline & RW & $0.12(0.02) \mathrm{a}$ & $0.31(0.10) \mathrm{a}$ & $2.96(0.16) \mathrm{a}$ & $1.31(0.36) \mathrm{a}$ & $3.30(0.89) \mathrm{a}$ & $31.89(3.12) \mathrm{a}$ \\
\hline & SI & 16.9 & 63.5 & 49.7 & - & - & - \\
\hline
\end{tabular}

Values followed by different small letters (different treatment) and different capital letters (different sampling data) are significantly different at $P<0.05$. SI: sensitivity index.

The correlations between SOC and labile organic C fractions were analyzed using all data detected from each site and replication. SOC content was significantly and positively correlated with $\mathrm{MBC}$ and $\mathrm{KMnO}_{4}-\mathrm{C}(P<0.01)$ (Table 6), indicating that $\mathrm{SOC}$ was a major determinant of $\mathrm{MBC}$ and $\mathrm{KMnO}_{4}-\mathrm{C}$. The improvement or depletion in $\mathrm{MBC}$ and $\mathrm{KMnO}_{4}-\mathrm{C}$ concentration could also give an early indication of the changes in SOC. Furthermore, a significant positive correlation was also observed between $\mathrm{MBC}$ and $\mathrm{KMnO}_{4}-\mathrm{C}$ (Table 6).

\section{Effect of irrigation on enzyme activities of soils}

Soil enzymes can be considered as potential indicators of nutrient cycling processes and soil quality because of their closely relationship with soil microorganisms. They can respond more rapidly to the changes in soil management and toxic contaminants compared to other soil variables[19]. In the present study, irrigation with RW for more than 20 years had significantly increased $\beta$-glucosidase, urease, alkaline phosphatase, arylsulphatase and dehydrogenase activities in the $0-20 \mathrm{~cm}$ soil compared to the GW irrigation $(P<0.05)$ (Table 5). These results reflected the stimulated microbial activity in RW irrigated soil, and might be attributed to the long-term additional input of organic matter and nutrients through river water irrigation. The nutrients from the river water not only provided substrate for the enzymatic reaction in the soil, but also made available for plants. Thus, active microorganism may make use of this plant-derived $\mathrm{C}$ for growth and enzyme production, thereby increasing soil enzyme activities. In addition, the higher SOC levels in the RW treatment may provide a favorable environment for the accumulation of enzymes in the surface soil, since soil organic matter is considered to be important in forming stable complexes with free enzymes[20].

The most sensitive enzymes to irrigation management were arylsulphatase and $\beta$-glucosidase, with mean SI values of 73.3 and 71.9 , respectively, indicating that they were good indicators of soil quality in the study area (Table 5). However, the significant increase of enzyme activity under RW irrigation was not observed in catalase activity, which showed a relatively low SI value at only 11.7. The enzyme activities, as well as labile organic $\mathrm{C}$ contents, were tested higher in May 2013 than in September 2012. The variation of these soil microbiological parameters might suggest that they are affected by seasonal trends in climate, crop system and agricultural practices. Nevertheless, although the microbial biomass is a very dynamic component of soil organic matter fluctuating with weather, the effect of irrigation on the biochemical parameters was independent of the seasonal variation and showed similar trend in the two sampling periods, revealing a consistency of the response to the irrigation management.

TABLE V. ENZYME ACTIVITIES IN SOILS

\begin{tabular}{|c|c|c|c|c|c|c|c|}
\hline & & GLU & URE & ALP & ARY & $\mathrm{DEH}$ & CAT \\
\hline \multirow[t]{3}{*}{ Sep 2012} & GW & $71.8(11.8) \mathrm{Ab}$ & $153.1(25.6) \mathrm{Ab}$ & $399.2(75.2) \mathrm{Ab}$ & $34.5(6.4) \mathrm{Ab}$ & $142.7(11.9) \mathrm{Bb}$ & $0.58(0.11) \mathrm{Aa}$ \\
\hline & RW & $116.4(23.3) \mathrm{Aa}$ & $213.0(32.6) \mathrm{Aa}$ & $496.6(73.8) \mathrm{Aa}$ & $52.1(10.8) \mathrm{Ba}$ & $202.1(12.8) \mathrm{Ba}$ & $0.67(0.09) \mathrm{Aa}$ \\
\hline & SI & 62.1 & 39.1 & 24.4 & 51.0 & 41.6 & 14.9 \\
\hline \multirow[t]{3}{*}{ May 2013} & GW & $74.2(9.7) \mathrm{Ab}$ & 161.1 (34.6)Ab & 418.3 (41.8)Ab & 35.7 (6.2)Ab & 157.4 (13.6)Ab & $0.65(0.07) \mathrm{Aa}$ \\
\hline & RW & $134.6(36.0) \mathrm{Aa}$ & $235.9(71.1) \mathrm{Aa}$ & $532.6(69.2) \mathrm{Aa}$ & 69.5 (18.4)Aa & $223.4(20.8) \mathrm{Aa}$ & $0.71(0.23) \mathrm{Aa}$ \\
\hline & $\begin{array}{c}\text { SI } \\
\text { GW }\end{array}$ & $\begin{array}{r}81.4 \\
73.0(8.8) b\end{array}$ & $\begin{array}{c}46.4 \\
157.1(28.8) b\end{array}$ & $\begin{array}{c}27.3 \\
408.8(46.3) b\end{array}$ & $\begin{array}{c}95.0 \\
35.1(4.2) b\end{array}$ & $\begin{array}{c}41.9 \\
150.0(10.5) b\end{array}$ & $\begin{array}{c}8.8 \\
0.62(0.07) a\end{array}$ \\
\hline \multirow{2}{*}{ Mean } & RW & $125.5(22.9) \mathrm{a}$ & $224.4(38.6) \mathrm{a}$ & $514.6(62.9) \mathrm{a}$ & $60.8(12.6) \mathrm{a}$ & $212.7(10.6) \mathrm{a}$ & $0.69(0.14) \mathrm{a}$ \\
\hline & SI & 71.9 & 42.9 & 25.9 & 73.3 & 41.8 & 11.7 \\
\hline
\end{tabular}


Means of three triplicates with standard deviation in parenthesis. Values followed by different small letters (different treatment) and different capital letters (different sampling data) are significantly different at $P<0.05$. SI: sensitivity index. GLU, $\mu \mathrm{g}$ PNP g ${ }^{-1} \mathrm{~h}^{-1}$; URE, $\mu \mathrm{g} \mathrm{NH_{4 } +}-\mathrm{N} \mathrm{g}^{-1}$ $2 \mathrm{~h}^{-1}$; ALP, $\mu \mathrm{g}$ PNP $\mathrm{g}^{-1} \mathrm{~h}^{-1}$; ARY, $\mu \mathrm{g}$ PNP g ${ }^{-1} \mathrm{~h}^{-1}$; DEH, $\mu \mathrm{g}$ TPF g $\mathrm{g}^{-1} 24 \mathrm{~h}^{-1}$; CAT, $\mathrm{ml} \mathrm{KMnO} \mathrm{Kg}^{-1} \mathrm{~h}^{-1}$.

Soil enzyme activities usually have a positive correlation with organic C contents. The pearson's correlation matrix revealed that the $\beta$-glucosidase, arylsulphatase, dehydrogenase and catalase activities were all significantly and positively correlated with SOC content (Table 6). Meanwhile, enzyme activities also significantly and positively correlated with labile organic $\mathrm{C}$ fractions (Table 6). Such correlations indicated that the labile organic $\mathrm{C}$ pools as substrate and its availability was an important determinant of enzyme activities in the soils. The results also showed that the enzymes activities (except catalase) were all significantly and positively correlated with each other $(P<0.01)$ (Table 6), suggesting that they are closely interrelated.

TABle VI. Correlations BetweEn SoIl ChEMiCAL AND Biochemical PARAMETERS

\begin{tabular}{|c|c|c|c|c|c|c|c|c|c|}
\hline & DOC & MBC & $\mathrm{KMnO}_{4}-\mathrm{C}$ & GLU & URE & ALK & ARY & DEH & CAT \\
\hline SOC & - & $0.724 * *$ & $0.747^{* *}$ & $0.482 *$ & - & - & $0.591^{*}$ & $0.818^{* *}$ & $0.548^{*}$ \\
\hline DOC & & - & - & $0.648^{* *}$ & $0.546^{*}$ & $0.496^{*}$ & - & - & - \\
\hline $\mathrm{MBC}$ & & & $0.654 * *$ & - & - & $0.516^{*}$ & $0.660 * *$ & $0.673^{* *}$ & $0.591 * *$ \\
\hline $\mathrm{KMnO}_{4}-\mathrm{C}$ & & & & $0.701 * *$ & $0.581^{*}$ & $0.547^{*}$ & $0.718^{* *}$ & $0.851 * *$ & - \\
\hline GLU & & & & & $0.815^{* *}$ & $0.858 * *$ & $0.869 * *$ & $0.813 * *$ & - \\
\hline URE & & & & & & $0.713 * *$ & $0.790^{* *}$ & $0.669^{* *}$ & - \\
\hline ALK & & & & & & & $0.850 * *$ & $0.752 * *$ & - \\
\hline ARY & & & & & & & & $0.793 * *$ & - \\
\hline DEH & & & & & & & & & - \\
\hline
\end{tabular}

Besides organic matter and nutrients, the river water used for irrigation also contained toxic contaminants such as heavy metals, which may pose long-term damaging effect on soil quality. Heavy metals accumulated in soils not only have negative effects on plant growth, but also affect soil microbial communities and their activities[21]. Previous studies had showed that microbial biomass and enzyme activities in the soil decreased with the increase of heavy metal concentrations[3]. The degree of there decreases varied depending on the types of enzymes. However, in our study, since enzyme activities and heavy metal concentrations are both increasing in the RW irrigated soil, it is not possible to conclude from the results whether the toxicity of heavy metals had influenced the microbial biomass. The influence of irrigation with river water on soil microbial activity should be considered as a combination effect of enhancement by nutrients and inhibition by toxic contaminants. Thus, it is of great importance to monitor the changes in soil quality parameters for safe use of the river water in agriculture. Moreover, in order to reduce the risk of wastewater irrigation on safety of crop quality and human health, further studies are needed to investigate the organic pollutants in the river water and irrigated soils.

\section{CONCLUSION}

The present study clearly showed that long-term irrigation with water from the Wangyang River, which received treated industrial wastewater as major water source, has resulted in significant increases of labile organic $\mathrm{C}$ contents and enzyme activities in the surface soil. The enhancement in soil microbiological properties can be attributed to the high organic load of the river water, which provided large amounts of organic compounds and nutrients to the soils, thus increased crop residues and stimulated microbial activity. On the other hand, long-term irrigation with this river water also resulted in accumulation of heavy metals in the surface soil. Although the heavy metal concentrations in the river water irrigated soils have not exceeded the recommended limit values, it may have potential risk to soil quality and food safety in the future. Therefore, a controlled irrigation management based on periodic monitoring of soil quality parameters should be considered to ensure safe and long-term use of the river water for irrigation in this area.

\section{ACKNOWLEDGEMENTS}

This study was funded by the Mega-projects of Science Research for Water Environment Improvement (No. 2012ZX07203003).

\section{REFERENCES}

[1] Wu, D.M., Zhang, C., Meng, F.Q. Economic loss evaluation of agricultural environmental pollution from wastewater irrigation in Hebei Province. Chinese J. Eco-Agr. 12, 176-179. 2004.

[2] Morugán-Coronado, A., García-Orenes, F., Mataix-Solera, J., et al. Short-term effects of treated wastewater irrigation on Mediterranean calcareous soil. Soil Till. Res. 112, 18-26, 2011.

[3] Kayikcioglu, H.H. Short-term effects of irrigation with treated domestic wastewater on microbiological activity of a Vertic xerofluvent soil under Mediterranean conditions. J. Environ. Manage. $102,108-114,2012$

[4] Mohammad, M.J., Mazahred, N. Changes in soil fertility parameters in response to irrigation of forage crops with secondary treated wastewater. Commun. Soil Sci. Plan. 34, 1281-1294, 2003. 
[5] Li, W.Z., Li, X.Y., Wang, H.L., et al. Spatial distribution of the main contaminations in aquatic environment in Fuyang River. Acta Sci. Circumst. 32, 2814-2819, 2012.

[6] Li, S.S., Shan, B.Q., Zhang, H. Characteristics and ecological risk assessment of heavy metal pollution in surface sediments of Fuyang River. Acta Sci. Circumst. 33, 2277-2284, 2013.

[7] Gee, G.W., Bauder, J.W. Particle-size analysis. In: Klute, A. (ed) Methods of soil analysis, Part 1. Physical and miner-alogical methods. Madison: ASA, pp. 399-411, 1986.

[8] Bao, S.D. Soil and agricultural chemistry analysis. China Agricultural Press, Beijing, pp. 370-403, 2000.

[9] Vance, E.D., Brookes, P.C., Jenkinson, D.S. An extraction method for measuring soil microbial biomass C. Soil Biol. Biochem. 19, 703-707, 1987.

[10]Dannenmann, M., Simon, J., Gasche, R., et al. Tree girdling provides insight on the role of labile carbon in nitrogen partitioning between soil microorganisms and adult European beech. Soil Biol. Biochem. 41, 1622-1631, 2009.

[11] Vieira, F.B.C., Bayer, C., Zanatta, J.A., et al. Carbon management index based on physical fractionation of soil organic matter in an Acrisol under long-term no-till cropping systems. Soil Till. Res. 96, 195-204, 2007.

[12] Zhou, Q.H., Wu, Z.B., Cheng, S.P., et al. Enzymatic activities in constructed wetlands and di- $n$-butyl phthalate (DBP) biodegradation. Soil Biol. Biochem. 37, 1454-1459, 2005.

[13] Tabatabai, M.A. Soil enzymes. In: Page, A.L., Miller, R.H., Keeney, D.R. (Eds.), Methods of Soil Analysis. Part 2. Chemical and Microbiological Properties. Soil Science Society of America,
Madison, pp. 903-947, 1982

[14] Buckland, G.D., Bennett, D.R, Mikalson, D.E., et al. Soil salinization and sodication from alternate irrigations with saline-sodic water and simulated rain. Can. J. Soil Sci. 82, 297-309, 2002.

[15] Friedel, J.K., Langer, T., Siebe, C., et al. Effects of long-term waste water irrigation on soil organic matter, soil microbial biomass and its activities in central Mexico. Biol. Fert. Soils 31, 414-421, 2000.

[16] Alvarez-Bernal, D., Contreras-Ramos, S.M., Trujillo-Tapia, N., et al. Effects of tanneries wastewater on chemical and biological soil characteristics. Appl. Soil Ecol. 33, 269-277, 2006.

[17] Chen, H.Q., Hou, R.X., Gong, Y.S., et al. Effects of 11 years of conservation tillage on soil organic matter fractions in wheat monoculture in Loess Plateau of China. Soil Till. Res. 106, 85-94, 2009.

[18] Powlson, D.S., Brookes, P.C., Jenkinson, D.S. Measurement of soil microbial biomass provides an early indication of changes in total soil organic matter due to straw incorporation. Soil Biol. Biochem. 19, 159-164, 1987.

[19] Bandick, A.K., Dick, R.P. Field management effects on soil enzyme activities. Soil Biol. Biochem. 31, 1471-1479, 1999.

[20] Marx, M.C., Kandeler, E., Wood, M., et al. Exploring the enzymatic landscape: distribution and kinetics of hydrolytic enzymes in soil particle-size fractions. Soil Biol. Biochem. 37, 35-48, 2005.

[21] Yim, M.W., Tam, N.F.Y. Effects of wastewater-borne heavy metals on mangrove plants and soil microbial activities. Mar. Pollut. Bull. 39, 179-186, 1999. 